\title{
Mammals recorded in isolated remnants of Atlantic Forest in southern Goiás, Brazil
}

\author{
Analice Calaça ${ }^{1 *}$, Marluci Fachi ${ }^{2}$, Diego Afonso Silva ${ }^{2}$, Seixas Rezende Oliveira ${ }^{2,3}$ \& \\ Fabiano Rodrigues de Melo ${ }^{1,4,5}$ \\ ${ }^{1}$ Universidade Federal de Goias, Regional Jatai, Jatai, BR 364, km 195, $n^{\circ} 3800$, Setor Estrela Dalva, \\ CEP 75801-615, GO, Brasil \\ ${ }^{2}$ Universidade do Estado de Mato Grosso, Programa de Pós-Graduação em Ecologia e Conservação, \\ Rua Prof. Dr. Renato Figueiro Varella, s/n, CEP: 78690-000, Nova Xavantina, MT, Brasil \\ ${ }^{3}$ Instituto Federal Goiano, Programa de Pós-Graduação em Biodiversidade e Conservação, Rodovia Sul \\ Goiana, Km 1, s/n, Zona Rural, CEP: 75.901-970, Rio Verde, GO, Brasil \\ ${ }^{4}$ Muriqui Instituto de Biodiversidade - MIB, Caratinga, MG, Brasil \\ ${ }^{5}$ Universidade Federal de Viçosa, Departamento de Engenharia Florestal, Viçosa, MG, Brasil \\ *Corresponding author: Analice Calaça, e-mail: analicecalaca@gmail.com
}

CALAÇA, A. FACHI, M, SILVA, D.A., OLIVEIRA, S. R., MELO, F. R. Mammals recorded in isolated remnants of Atlantic Forest in southern Goiás, Brazil. Biota Neotropica. 19(1): e20180575. http://dx.doi.org/10.1590/16760611-BN-2018-0575

\begin{abstract}
Habitat fragmentation is one of the principal causes of the decline of species worldwide, and the Brazilian Atlantic Forest and Cerrado savanna biomes are among the most severely affected by this process. While highly fragmented, remnants of Atlantic Forest can still be found within the Cerrado domain of southern Goiás, where previous studies have revealed high levels of biodiversity. To inventory the mammalian species that occur in the region, two fragments of semideciduous Atlantic Forest were sampled between 2011 and 2016, using line transect surveys and camera trapping. A total of 1016 records were obtained of 30 mammal species, of which eleven are under some threat of extinction. The species richness recorded on this study was similar to or higher than the values reported from other areas of Goiás, which reinforces the importance of the maintenance of these remnants, located in private properties, for the conservation of the region's mammals.

Keywords: survey, cameras traps, linear transect, medium- and large-sized mammals, spatial distribution, species richness.
\end{abstract}

\section{Mamíferos registrados em áreas isoladas de Mata Atlântica no sudoeste de Goiás}

Resumo: A fragmentação de hábitat é uma das principais causas do declínio das espécies e tanto a Mata Atlântica quanto o Cerrado são considerados um dos biomas mais afetados do mundo. As regiões sul e sudoeste de Goiás são intensamente fragmentadas, mas ainda abrigam alguns dos últimos remanescentes relictuais de Mata Atlântica dentro do domínio do Cerrado e estudos prévios revelaram uma alta biodiversidade. Com o objetivo de elaborar a lista de espécies de mamíferos que ocorrem para a região, dois fragmentos de florestas semideciduais da Mata Atlântica foram amostrados entre 2011 a 2016, através de transecções lineares e armadilhas fotográficas. Foram obtidos um total de 1.016 registros de 30 espécies de mamíferos, das quais onze estão ameaçadas de extinção. A alta riqueza registrada foi similar ou maior ao de outras áreas no Estado e reforça a importância da manutenção desses remanescentes localizados em propriedades particulares para a conservação das espécies.

Palavras-chave: amostragem, armadilhas fotográficas, transecto linear, médios e grandes mamíferos, distribuição espacial, riqueza. 


\section{Introduction}

Brazil is home to $10 \%$ of the world's terrestrial biota, and is considered to be one of the planet's most biodiverse countries (Mittermeier et al. 1997). The country's fauna includes more than 700 recognized mammal species, and additional taxa are expected to be discovered in the near future (Paglia et al. 2012). The Atlantic Forest is not only one of Brazil's most diverse biomes, but also has a high rate of endemism (Feio \& Caramaschi 2002), which led to its inclusion, together with the Cerrado savanna, in the world's 34 conservation hotspots defined by Mittermeier et al. (2005). The reduction and isolation of the remaining forests in these hotspots represent one of the principal and most pressing threats to global biodiversity (Cullen Jr et al. 2005, Schnell et al. 2013).

The Brazilian Atlantic Forest originally covered a total area of $1,315,460 \mathrm{~km}^{2}$, including part of 17 different states, corresponding to approximately $15 \%$ of the total area of Brazil (Ribeiro et al. 2009). Most of the state of Goiás is covered by Cerrado savanna formations (Morellato \& Haddad 2000), although $3 \%$ of the southern and southwestern extreme of the state were originally covered with Atlantic Forest, with a total area of 1,190,184 ha (Galindo-Leal \& Câmara 2003). However, only 30,386 ha of this forest has survived to the present day (Fundação SOS Mata Atlântica 2017). In Goiás, only two types of Atlantic Forest formation exist, seasonal deciduous forest and seasonal semi-deciduous forest, which are both characterized by leaf-fall during the dry season, in addition to the impacts of habitat fragmentation and the loss of local biodiversity (Campanili \& Prochnow 2006, Fundação SOS Mata Atlântica 2017).

Given the importance of the Atlantic Forest and its critical situation in the state, the government of Goiás created the Atlantic Forest State Park (Parque Estadual da Mata Atlântica: PEMA) with the support of the MAB/UNESCO program. As this conservation unit was created less than 13 years ago, its biodiversity is still relatively poorly-known, despite the small area of Atlantic Forest it protects. These remnant areas of Atlantic Forest require basic surveys to provide a reliable assessment of their conservation status, and in particular of the principal groups of organisms that provide the best indices of environmental quality. Vertebrates are among the most useful of these groups, especially as they represent the fauna for which the most scientific data are available. In the specific case of the Atlantic Forest, the birds and mammals are especially important, due to the fact that the include the majority of the endangered species (Chiarello et al. 2008).

Despite the importance of the Atlantic Forest, and its reduced area in Goiás, which as already been decimated by anthropogenic impacts, there are virtually no studies of the biota of this local ecosystem. Given this, the present study was conducted with the aim of expanding the inventory of medium and large mammals species available for the study area and contributing to the evaluation of the conservation status of the fragments, given that mammals are relatively reliable indicators of habitat quality.

\section{Material and Methods}

\section{Study Area}

The study area is composed of two fragments of Atlantic Forest, one of 2100 hectares $\left(18^{\circ} 55^{\prime} 41^{\prime \prime} \mathrm{S}, 51^{\circ} 42^{\prime} 41^{\prime \prime} \mathrm{W}\right)$ and the other of 2000 hectares (18 55'37' S, 51 ${ }^{\circ} 39^{\prime} 12^{\prime}$ ' W), set within a matrix of pasture, which are part of the PELD/Jataí Long-Term Ecological Monitoring Project, located in the municipalities of Aporé and Itajá, in Goiás, Brazil (Figure 1). This region encompasses the last remnants of the Atlantic Forest left in Goiás, which are complex and heterogeneous environments that have a high species richness (Melo et al. 2013). The region's climate is humid tropical, $A w$ in the Köppen classification system, with dry winters (April to September) and rainy summers (October to March), a mean temperature of $30^{\circ} \mathrm{C}$, and mean annual precipitation of 1486 $\mathrm{mm}$ (Melo et al. 2013).

\section{Data Collection}

The inventory of medium and large mammals was based on the data collected in two studies. The first study was conducted between April and July 2011, and consisted of visual surveys along three linear transects of $500 \mathrm{~m}$ in length established within the study fragments and on the roads that run along its edges. These surveys were conducted in the early morning (06:00-12:00 h) and late afternoon/early night (16:00-00:00 h). Additional data were collected using four Tigrinus camera traps, installed within the fragments, but outside the transects, during the first field trip, which were only removed during the last trip, in July 2011. The cameras were in operation 24 hours a day, and were visited monthly to change film and batteries, and to replace the bait, which was composed of sardine, pineapple, and salt. During three field trips, a total of 19 days of line transect surveys were conducted, and photographic records were collected during 192 trap-days.

During the second study, between December 2015 and March 2016, data were collected only by camera-trapping, with 10 Bushnell HD Trophy Cam camera traps being used in the same fragments surveyed during the first study. On this occasion, the camera traps were set in a linear arrangement, following the principal axis of the fragment, at a mean distance of $1 \mathrm{~km}$ from one another, $30 \mathrm{~cm}$ above the ground. No bait was used. A threshold of 1 hour was used to consider different records of the same species captured by the same trap to be independent sampling events. A total of 3337 trap-days were collected over a 15-month study period during this second sampling period.

The conservation status of each mammalian species recorded during the present study was obtained from the red list of the International Union for Conservation of Nature and Natural Resources (IUCN 2017), and the Brazilian list of threatened fauna (ICMBio-MMA 2016). Species taxonomy followed Paglia et al. (2012), with the updates of Delsuc et al. (2016) for the Cingulata, and the proposed order Cetartiodactyla (see Montgelard et al. 1997).

\subsection{Data Analysis}

For the statistical analysis, a species accumulation curve was obtained from the whole data set from the two study periods combined, using the Jackknife I estimator. As the detection probability of most mammals is highly heterogeneous, due to their mobility and variable behavior, the Jackknife estimator is considered to be the most appropriate procedure for the assessment of species richness (Brose et al. 2003, Brose \& Martinez 2004, Tobler et al. 2008). The Jackknife I procedure takes the frequency of the rarest species in the sample into account (Heltshe \& Forrester 1983) and was calculated in the EstimateS program (Colwell 2009). 
Mammals of Atlantic Forest in southern Goiás

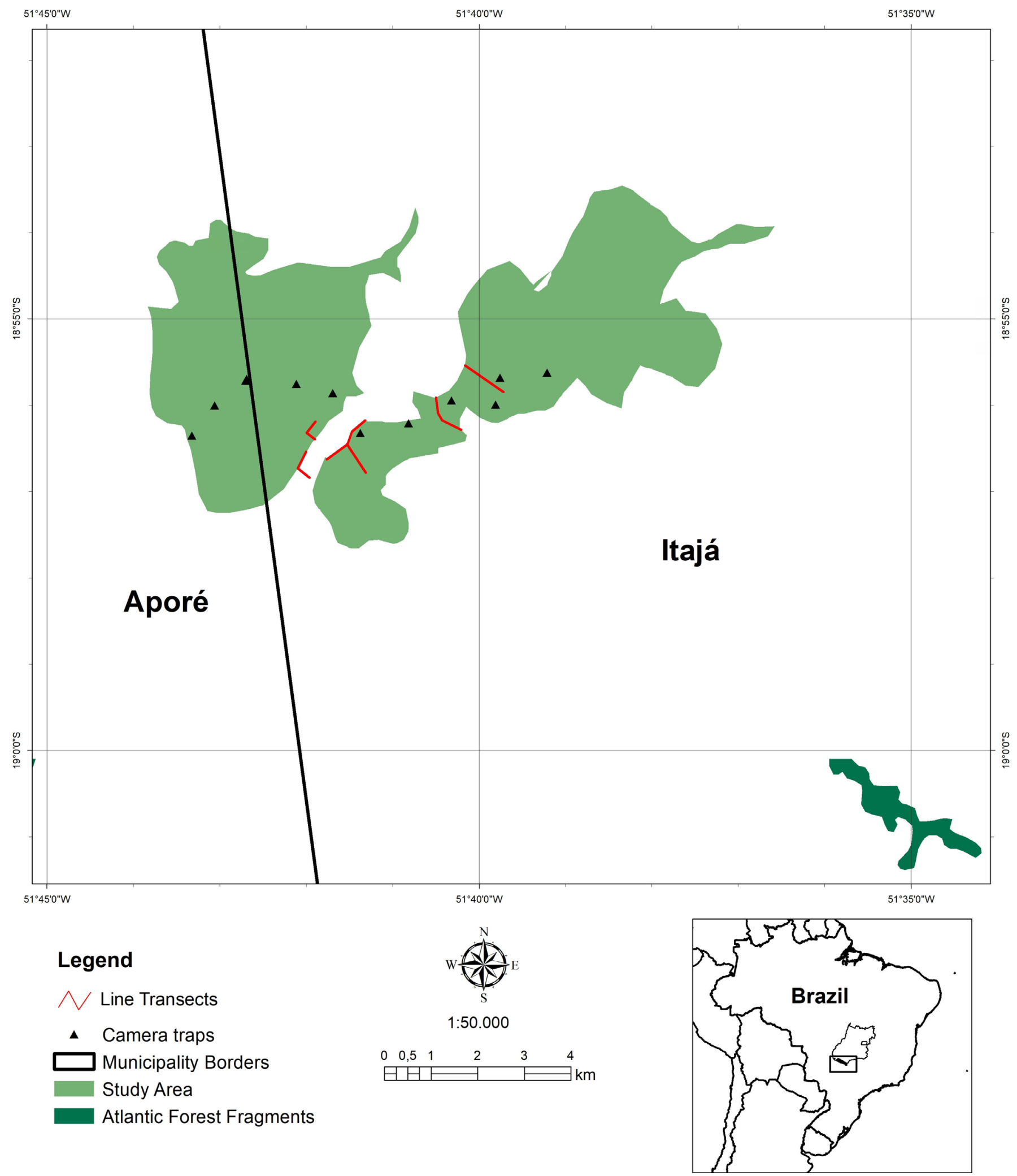

Figure 1. Location of the study area in the municipalities of Itajá and Aporé, in Goiás state, Brazil. The black dots indicate the locations at which the camera traps were installed during the second period and red lines are the linear transects. 


\section{Results}

A total of 1016 records were collected in the present study, which confirmed the presence of 27 mammal species of medium to large size. Three other species, the maned wolf (Chrysocyon brachyurus), the Neotropical otter (Lontra longicaudis), and the Brazilian porcupine (Coendou prehensilis), were also observed within the study area, but were not recorded during the fieldwork, so they were not included in the quantitative analyses. The final inventory thus contained 30 species of medium/large mammals, representing seven families and nine orders (Table 1, Figure 2).
Overall, 22 of the 27 species recorded in the fieldwork were registered in the line transect surveys, and five of these species were only recorded by this method. These species include the black howler monkey (Alouatta caraya), which rarely comes to the ground, the six-banded armadillo (Euphractus sexcinctus), the tapeti (Sylvilagus brasiliensis), and two carnivores, the hoary fox (Lycalopex vetulus) and the Pantanal cat (Leopardus braccatus). The camera traps also recorded 22 species and five exclusive taxa, all of which were terrestrial forms, including two armadillos, the southern naked-tailed armadillo (Cabassous unicinctus) and the nine-banded armadillo (Dasypus novemcinctus), the margay

Table 1. Mammals recorded in fragments of Atlantic Forest, southern Goiás state, Brazil. Type of record: $\mathrm{VO}=$ visual observation, $\mathrm{V}=$ vocalization, $\mathrm{T}=\mathrm{track}$, $\mathrm{F}=$ feces, $\mathrm{B}=$ burrow, $\mathrm{CT}=$ camera trap. Status of Conservation: VU= Vulnerable; NT= Near Threatened; LC $=$ Least Concern; $\mathrm{NC}=\mathrm{Not}$ Cited.

\begin{tabular}{|c|c|c|c|c|}
\hline \multirow[t]{2}{*}{ TAXON } & \multirow[t]{2}{*}{ COMMON NAME } & \multirow[t]{2}{*}{ TYPE OF RECORD } & \multicolumn{2}{|c|}{ CONSERVATION STATUS } \\
\hline & & & IUCN & MMA \\
\hline \multicolumn{5}{|l|}{ Order Didelphimorphia } \\
\hline Didelphis albiventris Lund, 1840 & White-eared Opossum & $\mathrm{VO}, \mathrm{CT}$ & $\mathrm{LC}$ & $\mathrm{NC}$ \\
\hline \multicolumn{5}{|l|}{ Order Cingulata } \\
\hline \multicolumn{5}{|l|}{ Family Chlamyphoridae } \\
\hline Cabassous unicinctus (Linnaeus, 1758) & Southern Naked-tailed Armadillo & $\mathrm{CT}$ & $\mathrm{LC}$ & $\mathrm{NC}$ \\
\hline Euphractus sexcinctus (Linnaeus, 1758) & Yellow Armadillo & $\mathrm{VO}, \mathrm{T}, \mathrm{B}$ & $\mathrm{LC}$ & $\mathrm{NC}$ \\
\hline Priodontes maximus (Kerr,1792) & Giant Armadillo & $\mathrm{B}, \mathrm{T}, \mathrm{CT}$ & VU & VU \\
\hline \multicolumn{5}{|l|}{ Family Myrmecophagidae } \\
\hline Tamandua tetradactyla (Linnaeus, 1758) & Southern Tamandua & $\mathrm{VO}, \mathrm{CT}$ & $\mathrm{LC}$ & $\mathrm{NC}$ \\
\hline \multicolumn{5}{|l|}{ Order Primates } \\
\hline \multicolumn{5}{|l|}{ Family Cebidae } \\
\hline Sapajus cay (Illiger, 1815) & Azara's Capuchin & $\mathrm{VO}, \mathrm{V}, \mathrm{CT}$ & $\mathrm{LC}$ & VU \\
\hline \multicolumn{5}{|l|}{ Family Atelidae } \\
\hline Alouatta caraya (Humboldt, 1812) & Black-and-gold Howler Monkey & $\mathrm{VO}$ & $\mathrm{LC}$ & $\mathrm{NC}$ \\
\hline \multicolumn{5}{|l|}{ Order Carnivora } \\
\hline \multicolumn{5}{|l|}{ Family Canidae } \\
\hline Cerdocyon thous (Linnaeus, 1766) & Crab-eating Fox & $\mathrm{VO}, \mathrm{V}, \mathrm{T}, \mathrm{F}, \mathrm{CT}$ & $\mathrm{LC}$ & $\mathrm{NC}$ \\
\hline Leopardus wieddi (Schinz, 1821) & Margay & $\mathrm{CT}$ & NT & $\mathrm{VU}$ \\
\hline Puma concolor (Linnaeus, 1771) & Puma & $\mathrm{T}, \mathrm{CT}$ & $\mathrm{LC}$ & VU \\
\hline Puma yagouaroundi (É. Geoffroy, 1803) & Jaguarundi & $\mathrm{CT}$ & $\mathrm{LC}$ & VU \\
\hline \multicolumn{5}{|l|}{ Family Mustelidae } \\
\hline Eira barbara (Linnaeus, 1758) & Tayra & $\mathrm{VO}, \mathrm{V}, \mathrm{CT}$ & $\mathrm{LC}$ & $\mathrm{NC}$ \\
\hline
\end{tabular}


Continuation Table 1.

\begin{tabular}{|c|c|c|c|c|}
\hline \multirow{2}{*}{$\begin{array}{l}\text { TAXON } \\
\text { Family Procyonidae }\end{array}$} & \multirow[t]{2}{*}{ COMMON NAME } & \multirow[t]{2}{*}{ TYPE OF RECORD } & \multicolumn{2}{|c|}{ CONSERVATION STATUS } \\
\hline & & & & \\
\hline Nasua nasua (Linnaeus, 1766) & South American Coati & $\mathrm{T}, \mathrm{CT}$ & $\mathrm{LC}$ & $\mathrm{NC}$ \\
\hline \multicolumn{5}{|l|}{ Order Perissodactyla } \\
\hline \multicolumn{5}{|l|}{ Order Artiodactyla } \\
\hline \multicolumn{5}{|l|}{ Family Tayassuidae } \\
\hline Pecari tajacu (Linnaeus, 1758) & Collared Peccary & $\mathrm{VO}, \mathrm{V}, \mathrm{T}, \mathrm{CT}$ & $\mathrm{LC}$ & \\
\hline Tayassu pecari (Link, 1795) & White-lipped Peccary & VO, V, T, CT & VU & VU \\
\hline \multicolumn{5}{|l|}{ Order Rodentia } \\
\hline \multicolumn{5}{|l|}{ Family Cuniculidae } \\
\hline Cuniculus paca (Linnaeus, 1766) & Spotted Paca & $\mathrm{T}, \mathrm{CT}$ & $\mathrm{LC}$ & $\mathrm{NC}$ \\
\hline \multicolumn{5}{|l|}{ Family Dasyproctidae } \\
\hline Dasyprocta azarae (Lichtenstein, 1823) & Azara's Agouti & VO, V, T, CT & DD & $\mathrm{NC}$ \\
\hline \multicolumn{5}{|l|}{ Erithizontidae } \\
\hline Coendou prehensilis (Linnaeus, 1758) & Brazilian Porcupine & $\mathrm{Vi}$ & $\mathrm{LC}$ & \\
\hline \multicolumn{5}{|l|}{ Order Lagomorpha } \\
\hline \multicolumn{5}{|l|}{ Family Leporidae } \\
\hline
\end{tabular}

(Leopardus wiedii) and the jaguarundi (Puma yagouaroundi), and the red brocket deer (Mazama americana).

The most diverse order was the Carnivora, with 10 species $(37.0 \%$ of the total number of species recorded), followed by the Cingulata and Cetartiodactyla, each with four species (14.8\% each). The number of species recorded per order varied negligibly between sampling procedures (Figure 3). The species accumulation curve reached the asymptote (Figure 4), which indicates that the sampling was sufficient to detect all the mammals in the study area, and while the estimate indicated the presence of an additional four species, three of these species would have been those recorded outside the fieldwork period.

\section{Discussion}

Local species inventories are essential for the assessment of the conservation status of a region's biodiversity, providing guidelines for the selection of priority areas for conservation (Diniz-Filho et al. 2008, Jenkins et al. 2015). In the present study, the use of different approaches for the collection of data maximized the chances of recording species, in particular the more cryptic forms that are difficult to observe, such as carnivores, providing the most representative possible sample of the local mammalian fauna, given the available time and resources (Silveira et al. 2003)
While comparisons with other studies may not be totally reliable, given differences in sampling effort and habitat characteristics, they do provide an important baseline for the quantification of a region's biodiversity (Gomes et al. 2015). The number of species recorded in the present study (30) was similar to or higher than those recorded in previous studies in southern Goiás. In the Atlantic Forest State Park, in the municipality de Água Limpa, for example, Rocha et al. (2015) recorded 23 species of medium to large-bodied mammals within a landscape that has few remnants of natural habitat, due to intense fragmentation, but is important for the maintenance of the region's fauna. Hannibal et al. (2015) recorded 25 species of medium/large mammals, including a number of endangered forms, in fragments of seasonal forest located on private properties in southern Goiás. In southwestern Goiás, within an area dominated by Cerrado savanna formations, Estrela et al. (2015) recorded 25 species in a fragment in Urutaí and Gomes et al. (2015) recorded 33 species in different phytophysionomies in the Serra do Facão range, in the municipalities of Catalão and Campo Alegre de Goiás.

On an ampler, and more directly comparable scale, the mammalian faunas recorded in fragments of Atlantic Forest in other regions of Brazil, such as São Paulo and Minas Gerais, were between 52\% and $67 \%$ similar to that recorded in the present study (Magioli et al., 2014; Machado et al., 2016; Laurindo et al., 2017; Bovo et al., 2018). 


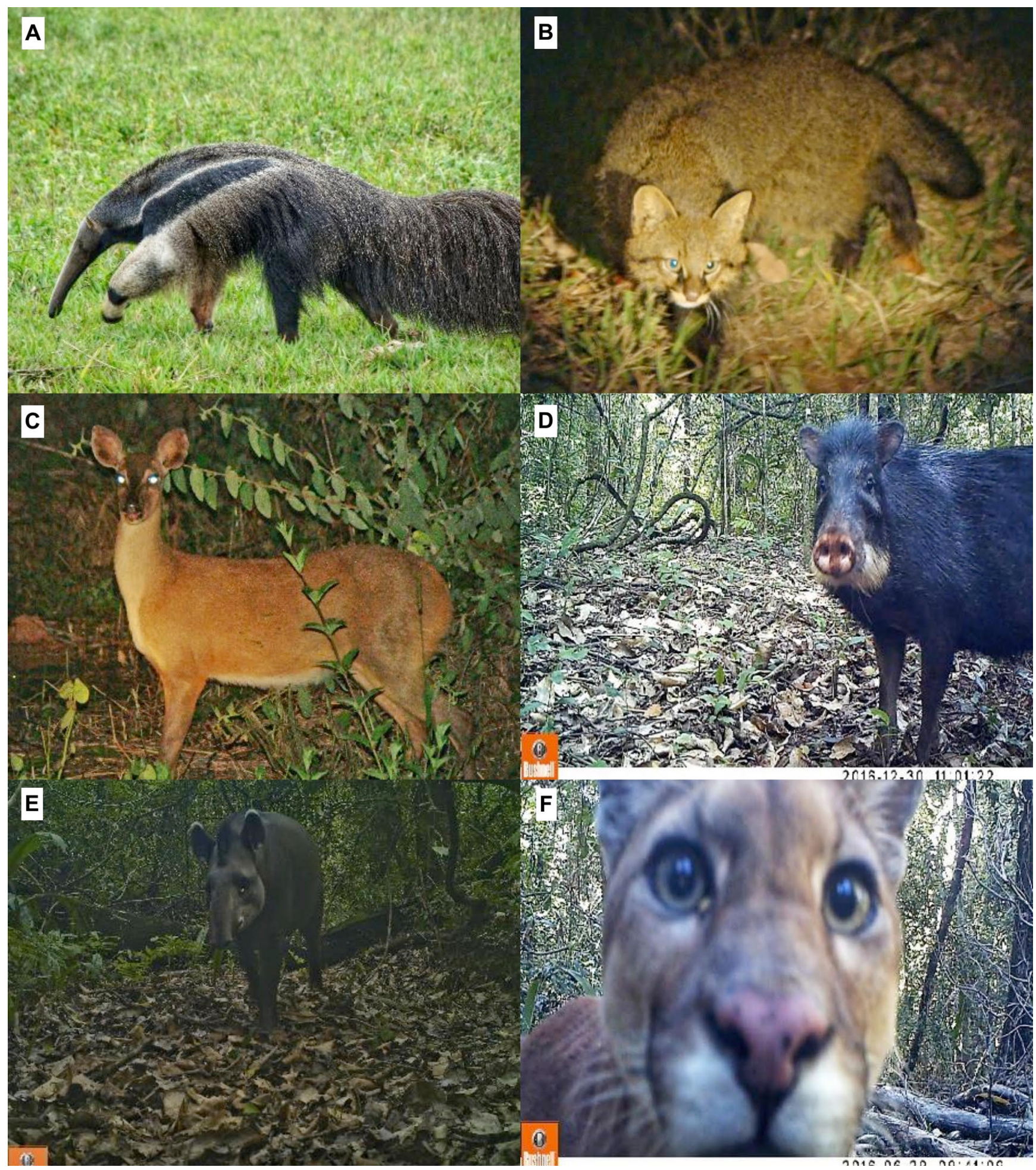

Figure 2. Some of the mammals recorded in fragments of Atlantic forest in southern Goiás state, Brazil: A) Myrmecophaga tridactyla; B) Leopardus braccatus; C) Mazama americana; D) Tayassu pecari; E) Tapirus terrestris; F) Puma concolor. 


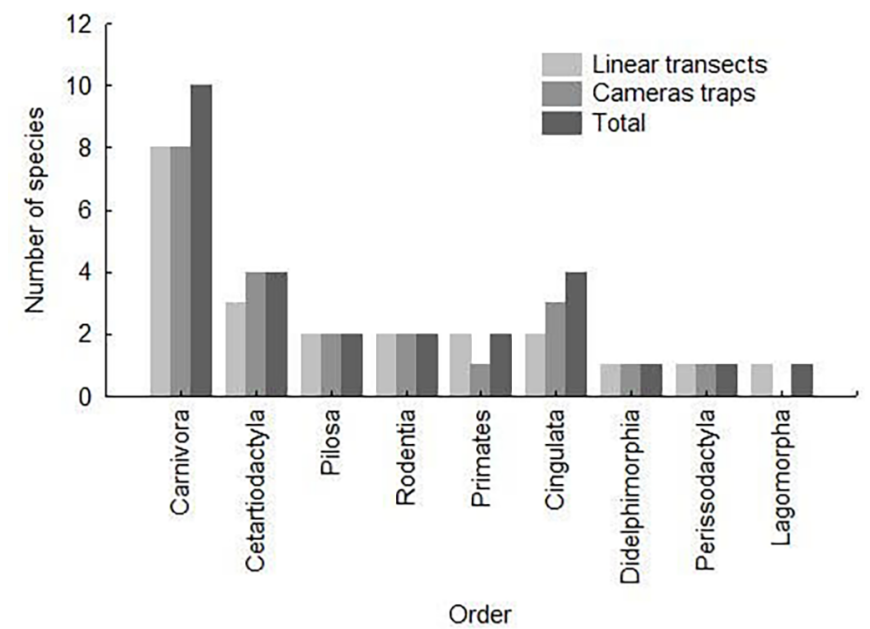

Figure 3. Records of the different mammalian orders obtained by linear transect surveys and cameras trapping in fragments of Atlantic Forest in southern Goiás state, Brazil.

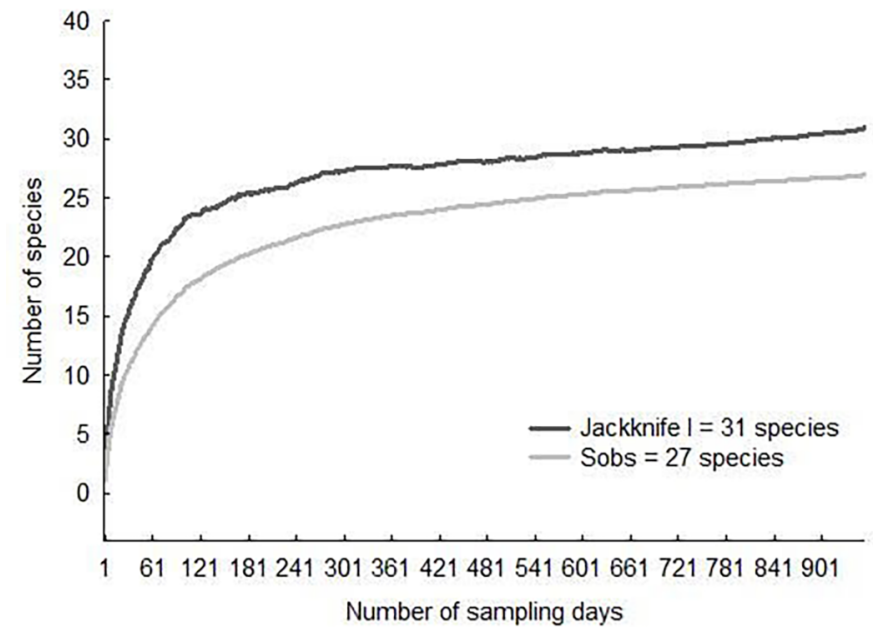

Figure 4. Accumulation curve of mammal species recorded in fragments of Atlantic Forest in southern Goiás state, Brazil.

The similarities were even greater in comparison with fragments of Cerrado savanna, protected or otherwise, with an average of $83 \%$ of species in common (Rodrigues et al., 2002; Bocchiglieri et al., 2010; Campos et al., 2013; Leite et al., 2016; Cabral et al., 2017), reflecting the considerable influence of this biome on the mammalian fauna of the study area.

The species richness recorded in the present study is probably also a reflection of the vegetation structure of the fragments surveyed, which are formed predominantly by seasonal semi-deciduous Atlantic Forest in transition with areas of Cerrado savanna (Melo et al. 2013). This vegetation mosaic is occupied by species that are common to both biomes, as well as species characteristic of the Cerrado, such as the maned wolf (Chrysocyon brachyurus), hoary fox (Lycalopex vetulus), and Pantanal cat (Leopardus braccatus), in addition to Azaras' capuchin monkey (Sapajus cay), whose range within the Cerrado domain is extended here (Gusmão et al. 2018). No exclusive Atlantic Forest species were recorded in this study.
These findings reinforce the importance of the study fragments for the conservation of the mammals, in particular the species under some threat of extinction. Just over a third (36.6\%) of the species recorded in the present study are classified in some category of threat in the two listings consulted (ICMBio-MMA, 2016; IUCN, 2017). A number of the species appear in both lists, and of these, the giant armadillo (Priodontes maximus), giant anteater (Myrmecophaga tridactyla), lowland tapir (Tapirus terrestris), and white-lipped peccary (Tayassu pecari) are all listed as vulnerable in both cases. Three other species, the Pantanal cat (L. braccatus), the margay (L. wiedii), and the maned wolf (C. brachyurus), are also listed as vulnerable by ICMBio-MMA (2016), but as "Near Threatened" by the IUCN (2017). Azaras' capuchin (S. cay), the hoary fox (Lycalopex vetulus), puma (Puma concolor), and jaguarundi (P. yagouaroundi) are all listed as vulnerable by the Brazilian environment ministry (ICMBio-MMA 2016).

As medium/large mammals, in particular carnivores, require relatively large areas to support a viable population (Costa et al. 2005), the environmental diversity of the fragments surveyed in the present study may be vital to the maintenance of the local populations of many of the species recorded in this study (Calaça et al. 2010, Rocha et al. 2015, Laurindo et al. 2017). Southern Goiás has suffered intense habitat fragmentation to make way for plantations of cash crops and cattle ranching, and these habitat remnants may represent vital refuges for many mammals. The protection of a region's biodiversity is essential to guarantee ecosystem function, in particular in fragmented landscapes, where interactions tend to break down as key species are lost (Camargo-Sanabria et al. 2015). Overall, then, the findings of the present study reemphasize the importance of the fragments surveyed for the conservation of the region's mammals and reinforce the urgent need for the creation of a conservation unit in this region, as proposed by Melo et al. (2013).

\section{Acknowledgements}

The authors are grateful to CNPq and FAPEG in the scope of the PELD Jataí Project (Process \# 2012/10267 00 1108), for the logistical and financial support and the owners of the farms for the authorization to sample the areas, particularly Paulinho and Cirlene for the receptivity. AMC thanks the CNPq/FAPEG for the DTI scholarship granted during the study.

\section{Author Contributions}

Analice Calaça: Substancial contribution in the concept and design of the study; Contribution to data collection; Contribution to data analysis and interpretation; Contribution to manuscript preparation; Contribution to critical revision, adding intelectual content.

Marluci Fachi: Contribution to data collection; Contribution to manuscript preparation.

Diego Afonso Silva: Contribution to data collection.

Seixas Rezende Oliveira: Contribution to data collection; Contribution to manuscript preparation.

Fabiano Rodrigues de Melo: Contribution to manuscript preparation; Contribution to critical revision, adding intelectual content. 


\section{Conflicts of interest}

The authors declare that they have no conflict of interest related to the publication of this manuscript.

\section{References}

BOCCHIGLIERI, A., MENDONÇA, A.F. \& HENRIQUES, R.P.B. 2010. Composição e diversidade de mamíferos de médio e grande porte no Cerrado do Brasil central. Biota Neotropica, 10 (3): 169-176.

BOVO, A.A.A., MAGIOLI, M., PERCEQUILLO, A.R., KRUSZYNSKI, C., ALBERICI, V., MELLO, M.A.R., CORREA, L.S., GEBIN, J.C.Z., RIBEIRO, Y.G.G., COSTA, F.B., RAMOS, V.N., BENATTI, H.R., LOPES, B., MARTINS, M.Z.A., DINIZ-REIS, T.R., CAMARGO, P.B., LABRUNA, M.B. \& FERRAZ, K.M.P.M.B. 2018. Human-modified landscape acts as refuge for mammals in Atlantic Forest. Biota Neotropica, 18 (2): e20170395.

BROSE, U., \& MARTINEZ, N. D. 2004. Estimating the richness of species with variable mobility. Oikos 105:292-300.

BROSE, U., MARTINEZ, N.D. \& WILLIAMS, R.J. 2003. Estimating species richness: sensitivity to sample coverage and insensitivity to spatial patterns. Ecology 84:2364-2377.

CABRAL, R., ZANIN, M., PORFÍRIO, G. \& BRITO, D. 2017. Medium-sized to large mammals of Serra do Tombador, Cerrado of Brazil. Check List 13(3): 2129

CALACA, A. M., MELO, F.R., DE MARCO JR., P., JÁCOMO, A.T. \& SILVEIRA, L. 2010. The influence of fragmentation on the carnivores distribution on a landscape of Cerrado. Neotrop. Biol. Conserv. 5 (1): 31-38.

CAMARGO-SANABRIA, A. A., MENDOZA, E., GUEVARA, R; MARTÍNEZRAMOS. M. \& DIRZO, R. 2015 Experimental defaunation of terrestrial mammalian herbivores alters tropical rainforest understorey diversity. Proc. R. Soc. B 282: 20142580

CAMPANILI, M. \& PROCHNOW, M. 2006. Mata Atlântica: uma rede pela floresta. Brasília: RMA. 322p.

CAMPOS, F.S., LAGE, A.R.B. \& RIBEIRO, P.H.P. 2013. Diversity of medium and large sized mammals in a Cerrado fragment of central Brazil. Journal of Threatened Taxa 5(15): 4994-5001.

CHIARELlO, A.G., AGUIAR, L.M.S., CERQUEIRA R.; MELO, F.R., RODRIGUES, F.H.G. \& SILVA, V.M. F. Mamíferos. 2008. In: MACHADO, A.B.M., DRUMMOND, G.M., PAGLIA, A.P. Livro vermelho da fauna brasileira ameaçada de extinção. 1 ed. Brasília, DF: MMA. p. 680-882.

COLWELL, R.K. 2009. EstimateS 8.2.0. - Statistical estimation of species richness and shared species from samples. http://viceroy. eeb.uconn.edu/ EstimateS.

COSTA, L.P., LEITE, Y.L.R., MENDES, S.L. \& DITCHFIELD, A.D. 2005. Conservação de mamíferos no Brasil. Megadiversidade 1(1): 104-112.

CULLEN JR., L., ALGER, K. \& RAMBALDI, D. M. 2005. Land reform and biodiversity conservation in Brazil in the 1990s: Conflict and the Articulation of Mutual Interests. Conserv. Biol. 19 (3): 747-755.

DELSUC, F., GIBB, G.C., KUCH, M., BILLET, G., HAUTIER, L., SOUTHON, J., ROUILLARD, J.M., FERNICOLA, J.C., VIZCAÍNO, S.F., MACPHEE, R.D.E. \& POINAR, H.N.P. 2016. The phylogenetic affinities of the extinct glyptodonts. Curr. Biol. 26: 155-156.

DINIZ-FILHO, J.A.F., BINI, L.M., PINTO, M.P., TERRIBILI, L.C., OLIVEIRA, G., VIEIRA, C.M., BLAMIRES, D., BARRETO, B.S., CARVALHO, P., RANGEL, T.F.L.V.B., TÔRRES, N.M. \& BASTOS, R.P. 2008. Conservation planning: a macroecological approach using the endemic terrestrial vertebrates of the Brazilian Cerrado. Oryx 42 (4): 567-577.

ESTRELA, D.C., SOUZA, D.C., SOUZA, J.M. \& CASTRO, A.L.S. 2015. Medium and large-sized mammals in a Cerrado area of the state of Goiás, Brazil. Check List 11 (4): 1-6.

FEIO, R.N. \& CARAMASCHI, U. 2002. Contribuição ao conhecimento da herpetofauna do nordeste do estado de Minas Gerais, Brasil. Phyllomedusa 1(2):105-111.
FUNDAÇÃO SOS MATAATLÂNTICA\& INPE. 2017. Atlas dos remanescentes florestais da Mata Atlântica, período 2015-2016. Relatório Técnico. São Paulo, SP.

GALINDO-LEAL, C. \& CÂMARA, I.G. 2003. Atlantic Forest hotspot status: an overview. In: The Atlantic Forest of South America: biodiversity status, trends, and outlook (C. Galindo-Leal \& I.G. Câmara, eds.). Center for Applied Biodiversity Science and Island Press, Washington, p. 3-11.

GOMES, L.P., ROCHA, C.R., BRANDÃO, R.A., \& MARINHO-FILHO, J. 2015. Mammal richness and diversity in Serra do Facão region, Southeastern Goiás state, central Brazil. Biota Neotropica 15 (4): 1-11.

GUSMÃO, A.C., OLIVEIRA, R.F., SILVA, O.D., MELO, F.R. \& SANTOSFILHO, S. 2018. An extension of the known geographic distribution of Sapajus cay (Illiger, 1815) (Primates, Cebidae) in southwestern Brazilian Amazonia. Check List 14 (1): 11-14.

HANNIBAL, W., FIGUEIREDO, V.V., CLARO, H.W.P., CARVALHO, A.C., CABRAL, G.P., OLIVEIRA, R.F., AQUINO, H.F., VIANA, F.V., SILVEIRO, T.F. \& FILHO, J.J.S. 2015. Mamíferos não-voadores em fragmentos de Cerrado no sul do estado de Goiás, Brasil. Boletim da Sociedade Brasileira de Mastozoologia 74: 103-109.

HELTSHE, J.F. \& FORRESTER, N. E. 1983. Estimating species richness using the jackknife procedure. Biometrics 39 (1): 1-11.

ICMBIO-MMA (Instituto Chico Mendes, Ministério do Meio Ambiente). 2016. Sumário Executivo do Livro Vermelho da fauna brasileira ameaçada de extinção. http://www.icmbio.gov.br/portal/images/stories/comunicacao/ publicacoes/publicacoesdiversas/dcom sumario executivo livro vermelho_ed_2016.pdf (ultimo acesso em: 23/04/2018).

INTERNATIONAL UNION FOR CONSERVATION OF NATURE AND NATURAL RESOURCES. 2017. The IUCN Red List of Threatened Species. Version 2017-3. <www.iucnredlist.org>. Downloaded on 01 March 2018.

JENKINS, C.N., ALVES, M.A.S., UEZU, A. \& VALE, M.M. 2015. Patterns of vertebrate diversity and protection in Brazil. PLoS ONE, 10 (12): e0145064.

LAURINDO, R.S., NOVAES, R.L.M., SOUZA, R.F., SOUZA, V.F., FELIX, F., SOUTO, T.M., CUNHA, R.G.T. \& GREGORIN, R. 2017. Mammals in forest remnants of an ecotonal Atlantic Forest-Cerrado area from southeastern Brazil. Neotrop. Biol. Conserv 12(1): 19-29.

LEITE, R.J.V., LEMOS, J.L.F., SILVA, F.W.M.D., ALENCAR, I.R.C.D., BEZERRAAND, P.F. \& CARREGARO, J.B. 2016. Composition of medium and large mammals in forest reserve in the Cerrado of Brazil Central. Revista Árvore 40: 825-832

MACHADO, F.S., ALMEIDA, A.F., BARROS, D.A., PEREIRA, J.A.A., SILVA, R.A., \& PEREIRA, A.A.S. 2016. Diversity of medium-sized and large mammals from Atlantic Forest remnants in southern Minas Gerais state, Brazil. Check List, 12(5): 1962.

MAGIOLI, M., BARROS-FERRAZ, K.M.P.M. \& RODRIGUES, M.G.. 2014. Medium and large-sized mammals of an isolated Atlantic Forest remnant, southeast São Paulo State, Brazil. Check List 10(4): 850-856.

MELO, F. R. M. (Org.). 2013. Proposta de Criação do Parque Estadual Tovacuçu, entre os Municípios de Itajá e Aporé, Goiás. Relatório Final - Contrato SEMARH/FUNAPE. 308p.

MITTERMEIER, R.A., ROBLES, G.P. \& MITTERMEIER C.G. 1997. Megadiversity: Earth's biologically wealthiest Nations. CEMEX and Agrupación Sierra Madre.

MITTERMEIER, R.A., GIL, R.P., HOFFMAN, M., PILGRIM, J., BROOKS, T., MITTERMEIER, C.G., LAMOREUX, J., FONSECA \& G.A.B. 2005. Hotspots revisited: Earth's biologically richest and most endangered terrestrial ecoregions. 2 ed., University of Chicago Press, Boston.

MONTGELARD, C., CATZEFLIS, F.M. \& DOUZERY, E. 1997. Phylogenetic relationships of artiodactyls and cetaceans as deduced from the comparison of cytochrome $b$ and 12S rRNA mitochondrial sequences, Mol. Biol. Evol. 14 (5): 550-559.

MORELLATO, L.P.C. \& HADDAD, C.F.B. 2000. Introduction: The Brazilian Atlantic Forest. Biotropica 32: 786-792. 
PAGLIA, A.P., RYLANDS, A.B., HERRMANN, G., AGUIAR, L.M.S., CHIARELLO, A.G., LEITE, Y.L.R., COSTA, L.P. \& SICILIANO, S. 2012. Lista Anotada dos Mamíferos do Brasil. 2a Edição. Conservation International, Arlington.

RIBEIRO, M.C., METZGER, J.P., MARTENSEN, A.C., PONZONI, FJ. \& HIROTA, M.M. 2009. The Brazilian Atlantic Forest: How much is left, and how is the remaining forest distributed? Implications for conservation. Biol. Conserv. 142: 1141-1153.

RODRIGUES, F.H.G., SILVEIRA, L., JÁCOMO, A.T.A., CARMIGNOTTO, A.P., BEZERRA, A.M.R., COELHO, D.C., GARBOGINI, H., PAGNOZZI, J. \& HASS, A. 2002. Composição e caracterização da fauna de mamíferos do Parque Nacional das Emas, Goiás, Brasil. Revista Brasileira De Zoologia, 19: $589-600$
ROCHA, E.C., SOARES, K.L. \& PEREIRA, I.M. 2015. Medium- and largesized mammals in Mata Attântica State Park, southeastern Goiás, Brazil. Chek List 11(6): 1-7.

SCHNELL JK., HARRIS GM., PIMM SL., RUSSELL GJ. 2013. Quantitative analysis of forest fragmentation in the Atlantic Forest reveals more threatened bird species than the current red list. PLoS ONE 8(5):e2206.

SILVEIRA, L., JÁCOMO, A.T.A. \& DINIZ-FILHO, J.A.F. 2003. Camera trap, line transect census and track surveys: a comparative evaluation. Biol Conserv. 114:351-355.

TOBLER, M.W., CARRILLO-PERCASTEGUI, S.E., LEITE PITMAN, R., MARES, R., \& POWELL, G. 2008. An evaluation of camera traps for inventorying large- and medium-sized terrestrial rainforest mammals. Anim. Conserv. 11:169-178. 